\title{
Macrophage heterogeneity and differentiation: defined serum-free culture conditions induce different types of macrophages in vitro
}

\author{
M. Kreutz, S.W. Krause, B. Hennemann, A. Rehm and R. Andreesen ${ }^{(*)}$ \\ Medizinische Klinik, Abteilung Innere Medizin I, Franz-Josef-Strauss-Allee 1, 8400 Regensburg (Germany)
}

\section{SUMMARY}

Macrophages (MAC) are important effector cells of the immune system. They arise from circulating blood monocytes (MO), which undergo further maturation upon leaving the vasculature and migrating into the various tissues and body cavities. A similar differentiation process can be followed in vitro when monocytes are cultured in the presence of serum. In this study, different factors and serum proteins, either alone or in combination, were tested for their ability to promote the survival and/or maturation of blood MO in the absence of serum. Elutriation-purified MO cultured for 8 days on hydrophobic teflon foils in the presence of $5 \%$ human serum differentiated into large, well-spread MAC, whereas in the absence of serum, MO rapidly died. The serum-induced maturation of MAC was accompanied by a strong expression of CD16, CD14 and MAX antigens. Secretion of TNF-alpha and neopterin increased about 10-fold as compared with freshly isolated MO.

The replacement of serum by either M-CSF (100 $\mathrm{ng} / \mathrm{ml})$ or immunoglobulin (0.5-5 $\mathrm{mg} / \mathrm{ml}$ ) had a marked effect on MO survival (about $50 \%$ of serum-cultured MO), but cells were smaller, less spread out and had low expression of CD16, CD14 and MAX antigens. Their functional competence in terms of TNF-alpha and neopterin release was reduced to $10-20 \%$ as compared with MAC cultured in the presence of serum. Both albumin $(0.5-5 \mathrm{mg} / \mathrm{ml})$ and 1,25-dihydroxyvitamin $D_{3}\left(1,25(O H)_{2} D_{3}\right)\left(10^{-8} \mathrm{M}\right)$ as substitutes for serum were less effective in terms of MO survival 120-30\% of serum-cultured MO), but were comparable to serum with respect to morphology and phenotype; however, they induced MAC with lower secretory activity. A combination of $1,25(\mathrm{OH})_{2} \mathrm{D}_{3}$ or albumin $(0.5 \mathrm{mg} / \mathrm{ml})$ with immunoglobulin $(0.5 \mathrm{mg} / \mathrm{ml})$ resulted in MAC showing serum-cultured characteristics in terms of phenotype, but lower secretory capacity and survival rate. However, the combination of the three factors together could substitute for serum in all parameters tested. The same result was obtained by cultivation of MO with high concentrations of albumin $(5 \mathrm{mg} / \mathrm{ml})$ and immunoglobulin $(5 \mathrm{mg} / \mathrm{ml})$. Other factors tested had no effect on the MO into MAC differentiation process (transferrin, vitamin $A$, fibronectin, vitamin $\left.D_{2}\right\}$.

In summary, we describe defined serum-free culture conditions for the generation of distinct types of MAC, which differ in terms of phenotype, morphology and function.

Submitted October 10, 1991, accepted November 15, 1991.

$\left({ }^{*}\right)$ For correspondence. 
Our system may be useful to study regulatory signals operative during the ontogeny of human MAC. It may be especially helpful to distinguish between competence/survival and maturation-inducing activities.

Key-words: Monocyte, Macrophage, Maturation; Differentiation, Serum, Proteins, Ontogeny.

\section{Introduction}

Monocytes (MO) are released from the bone marrow and circulate in the blood stream as a precursor pool for the heterogenous cells that constitute the mononuclear phagocyte system (MPS) (Unanue and Allen, 1987; van Furth, 1982). Monocyte to macrophage (MAC) differentiation also occurs in vitro when MO are cultured in the presence of serum (Musson, 1983; Johnson et al., 1977). This in vitro maturation is accompanied by characteristic changes in morphology and phenotype : cells become larger and spread out, and the expression of maturationassociated antigens (CD16, MAX antigens) is increased (Clarkson and Ory, 1988; Andreesen et al., $1986,1990)$. Besides these changes, there are differences in the functional activity of $\mathrm{MO}$ as compared to MAC. The capacity to secrete fibronectin, neopterin or TNF-alpha is increased several-fold during the maturation of MO into MAC, whereas other functions such as the secretion of interleukin-1 (IL1) and interleukin-6 (IL6) are decreased (Yamauchi et al., 1987; Scheibenbogen and Andreesen, 1991 ; Wewers and Herzyk, 1989).

Maturation-inducing factors present in serum have not yet been clearly identified. Cytokines like interleukin-4 (IL4) and macrophage colonystimulating factor (M-CSF) were discussed as possible mediators for the MO differentiation process (Becker et al., 1987; Te Velde, 1988). Some reports have implicated serum proteins like human immunoglobulins and fibronectin in the generation of MAC (Akiyama et al., 1988; Schreiber et al., 1991). 1,25-dihydroxyvitamin $\mathrm{D}_{3}\left(1,25(\mathrm{OH})_{2} \mathrm{D}_{3}\right)$, the active metabolite of vitamin $D_{3}$, has also been shown to induce differentiation of blood $\mathrm{MO}$ in vitro (Kreutz and Andreesen, 1990; Choudhuri et al., 1990).

In the present study, we compared the maturation-inducing capacity of distinct serum proteins (immunoglobulin, albumin, fibronectin), $\mathrm{M}-\mathrm{CSF}$ and $1,25(\mathrm{OH})_{2} \mathrm{D}_{3}$ alone or in combination and analysed cells grown in the presence of these factors in terms of morphology, phenotype and functional activity. We show that maturation-inducing activity in human serum cannot be replaced by one factor alone, but seems to consist of multiple factors. M-CSF and immunoglobulin promote survival of $\mathrm{MO}$, giving rise to MAC which are "immature" in terms of functional activity and phenotype. The combination of $1,25(\mathrm{OH})_{2} \mathrm{D}_{3}$, albumin and immunoglobulin led to MAC with functional and phenotypic features comparable serum-culturederived MAC.

\section{Materials and methods}

Cell separation and culture. - Peripheral blood mononuclear cells (MNC) were separated by leukapheresis of healthy donors, followed by density gradient centrifugation over Ficoll/Hypaque. MO were isolated from MNC by countercurrent centrifugal elutriation in a "J6M-E Beckmann" centrifuge with a large chamber and a JE-5 rotor at 2,500 rpm and a flow rate of $110 \mathrm{ml} / \mathrm{min}$ in Hank's balanced salt solution with $2 \%$ human albumin. Elutriated MO were $>90 \%$ pure as determined by morphology and antigen phenotype. Purified MO were cultured on teflon foils (Biofolie 25, Heraeus, Hanau, Germany) for 8 days at a cell density of $10^{6}$ cells $/ \mathrm{ml}$ in RPMI 1640 (Biochrom, Berlin, Germany) supplemented with $5 \times 10^{-5} \mathrm{M}$ mercaptoethanol, polyvitamins, antibiotics, pyruvate and non-essential amino acids (Andreesen et al., 1983). The following additives were tested for maturation-inducing activity: $5 \%$ pooled human AB-group serum (control), human albumin (preparation for clinical use, Biotest, Dreieich, Germany; $0.5-5 \mathrm{mg} / \mathrm{ml}$ ), human immunoglobulin (Sandoglobin; preparation for clinical use, Sandoz, Basel, Switzerland), $100 \mathrm{ng} / \mathrm{ml}$ rhM-CSF (Cetus Corporation, Emeryville, CA) and $10^{-7} \mathrm{M}-10^{-10} \mathrm{M} 1,25$-dihydroxyvitamin $\mathrm{D}_{3}$ or

\footnotetext{
ELISA = enzyme-linked immunosorbent assay.

M-CSF = macrophage colony-stimulating factor

$\mathrm{mAb}=$ monoclonal antibody.

MAC = macrophage

MNC = mononuclear cell.
} 


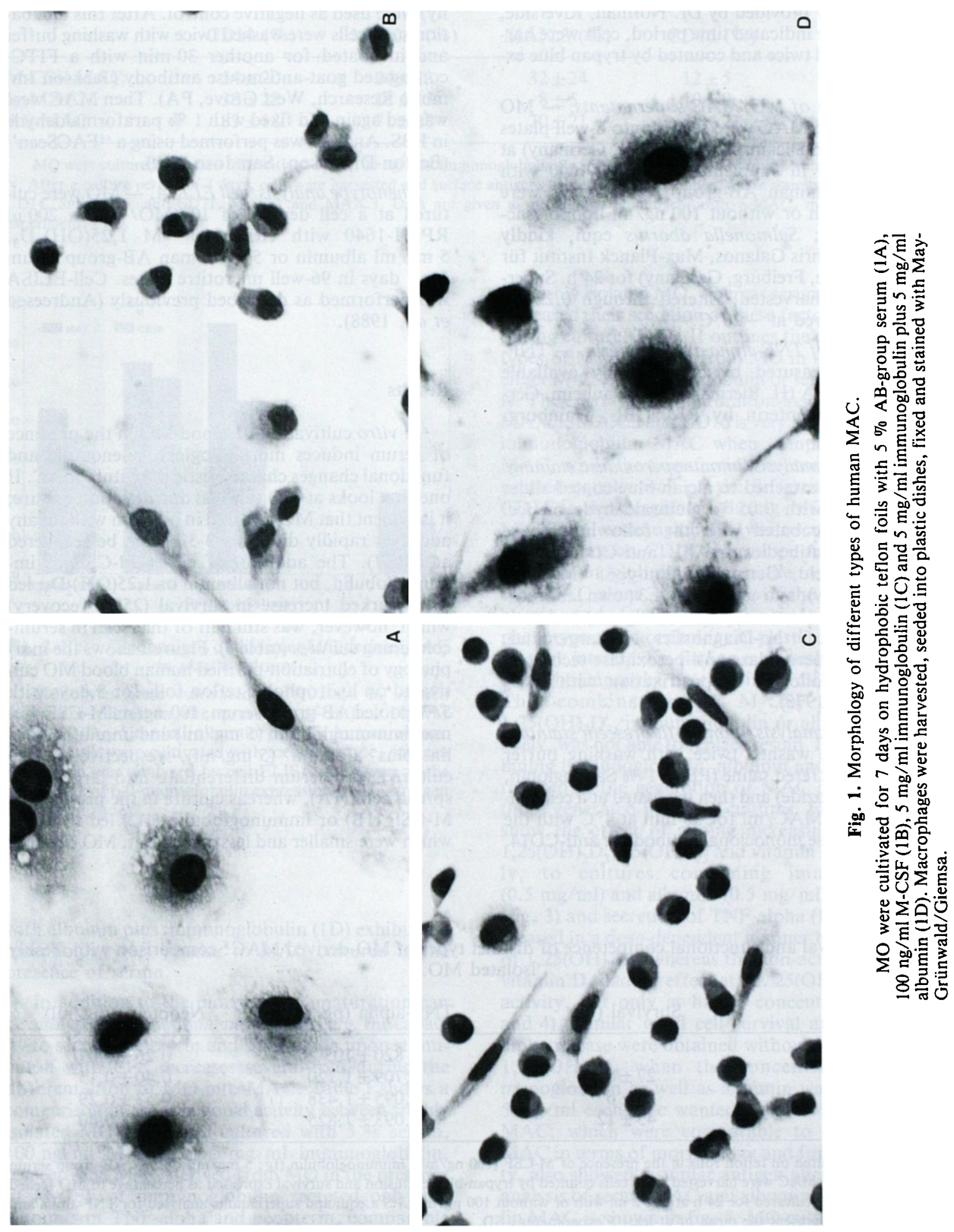


25-hydroxyvitamin $\mathrm{D}_{3}\left(25(\mathrm{OH})_{3}\right)$ (kindly provided by Hoffman-La Roche, Basel, Switzerland) or vitamin $D_{2}$ (kindly provided by Dr. Norman, Riverside, CA). After the indicated time period, cells were harvested, washed twice and counted by trypan blue exclusion.

Production of MO/MAC supernatants. - MO or MO-derived MAC were seeded into 6-well plates (Falcon/Becton-Dickinson, Heidelberg, Germany) at $10^{6}$ cells $/ 2 \mathrm{ml}$ in supplemented RPMI- 1640 with $2 \%$ pooled human AB-group serum. Cells were stimulated with or without $100 \mathrm{ng} / \mathrm{ml}$ lipopolysaccharide (LPS; Salmonella abortus equi, kindly provided by Chris Galanos, Max-Planck Institut für Immunbiologie, Freiburg, Germany) for $24 \mathrm{~h}$. Supernatants were harvested, filtered through $0.22-\mu \mathrm{m}$ filters and stored at $-20^{\circ} \mathrm{C}$.

Detection of TNF-alpha and neopterin. - TNFalpha was measured by commercially available sandwich-ELISA (H. Biermann, Bad Nauheim, Germany), and neopterin by RIA (IBL, Hamburg, Germany).

Phenotype analysis/immunoperoxidase staining. - MAC were attached to alcian-blue-coated slides and prefixed with $0.05 \%$ glutaraldehyde on ice. They were incubated with the following mouse monoclonal antibodies (mAb): anti-CD14 (My4; Coulter, Krefeld, Germany), anti-gp65 (MAX.1; own laboratory), anti-gp68 (MAX.3; own laboratory), anti-CD16 (Janssen, Beerse, Belgium) and antiCD71 (OKT9; Ortho-Diagnostics, Neckargemünd, Germany). A peroxidase anti-peroxidase technique was applied followed by postfixation with $\mathrm{OsO}_{4}$ (Bross et al., 1978).

Phenotype analysis/immunofluorescent staining. - MAC were washed twice with washing buffer (phosphate-buffered saline (PBS), $1 \%$ Sandoglobin, $0.1 \%$ sodium azide) and then incubated at a cell density of $5 \times 10^{5} \mathrm{MAC} / \mathrm{ml}$ for $30 \mathrm{~min}$ at $4^{\circ} \mathrm{C}$ with the following mouse monoclonal antibodies: anti-CD14, anti-gp65 (MAX.1) and anti-CD16. Polyclonal mouse immunoglobulins (Coulter, Krefeld, Germany) were used as negative control. After this incubation step, cells were washed twice with washing buffer and incubated for another $30 \mathrm{~min}$ with a FITCconjugated goat-anti-mouse antibody (Jackson Immuno Research, West Grove, PA). Then MAC were washed again and fixed with $1 \%$ paraformaldehyde in PBS. Analysis was performed using a "FACScan" (Becton-Dickinson, San Jose, CA).

Phenotype analysis/cell ELISA. - MO were cultured at a cell density of $10^{5} \mathrm{MO} /$ well in $200 \mu \mathrm{l}$ RPMI-1640 with either $10^{-9} \mathrm{M} 1,25(\mathrm{OH})_{2} \mathrm{D}_{3}$, $5 \mathrm{mg} / \mathrm{ml}$ albumin or $5 \%$ human AB-group serum for 7 days in 96-well microtitre plates. Cell-ELISA was performed as described previously (Andreesen et al., 1988).

\section{Results}

In vitro cultivation of blood MO in the presence of serum induces morphological, phenotypic and functional changes characteristic of mature MAC. If one first looks at MO survival during teflon culture, it is evident that MO cultured in medium without any additives rapidly die (only $3-5 \%$ can be recovered at day 7). The addition of either M-CSF or immunoglobulin, but not albumin or $1,25(\mathrm{OH})_{2} \mathrm{D}_{3}$, led to a marked increase in survival ( $25 \%$ recovery) which, however, was still half of that seen in serumcontaining cultures (table I). Figure 1 shows the morphology of elutriation-purified human blood MO cultivated on hydrophobic teflon foils for 8 days with $5 \%$ pooled AB-group serum, $100 \mathrm{ng} / \mathrm{ml} \mathrm{M-CSF}$, human immunoglobulin $(5 \mathrm{mg} / \mathrm{ml})$ and immunoglobulin plus albumin $(5 \mathrm{mg} / \mathrm{ml})$, respectively. $\mathrm{MO}$ cultured with serum differentiate into large, wellspread cells (1A), whereas culture in the presence of M-CSF (1B) or immunoglobulin (1C) led to MAC which were smaller and less spread out. MO cultured

Table I. Survival and functional competence of distinct types of MO-derived MAC: comparison with freshly isolated MO.

\begin{tabular}{lccc} 
& Survival (\%) & TNF-alpha $(\mathrm{pg} / \mathrm{ml})$ & Neopterin $(\mathrm{ng} / \mathrm{ml})$ \\
\hline MO & & $820 \pm 705$ & $0.26 \pm 0.07$ \\
M-CSF-MAC & $27 \pm 8$ & $1,709 \pm 1,720$ & $0.40 \pm 0.15$ \\
Ig-MAC & $25 \pm 6$ & $3,095 \pm 1,438$ & $0.53 \pm 0.29$ \\
AB-MAC & $45 \pm 12$ & $12,093 \pm 7,825$ & $1.32 \pm 0.40$ \\
\hline
\end{tabular}

MO were cultured on teflon foils in the presence of M-CSF $(100 \mathrm{ng} / \mathrm{ml})$, immunoglobulin $(\mathrm{Ig} ; 5 \mathrm{mg} / \mathrm{ml})$ or $5 \%$ AB-group serum (AB), respectively. MAC were harvested, vital cells counted by trypan-blue exclusion and survival expressed as percentage of $M O$ seeded initially. Cells were cultured for $24 \mathrm{~h}$ at $10^{6} / 2 \mathrm{ml}$ with or without $100 \mathrm{ng} / \mathrm{ml} \mathrm{LPS} \mathrm{a.equi} \mathrm{and} \mathrm{supernatants} \mathrm{analysed} \mathrm{for} \mathrm{TNF-alpha} \mathrm{and}$ neopterin. Data represent the mean of at least 5 experiments $\pm S D$. 
Table II. Phenotype analysis of MO-derived macrophages.

\begin{tabular}{lccccc} 
& CD14 (\%) & MAX.1 $(\%)$ & MAX.3 $(\%)$ & CD16 (\%) & CD71 (\%) \\
\hline M-CSF-MAC & $54 \pm 20$ & $24 \pm 13$ & $32 \pm 24$ & $12 \pm 5$ & $68 \pm 25$ \\
Ig-MAC & $38 \pm 22$ & $18 \pm 15$ & $8 \pm 5$ & $10 \pm 9$ & $37 \pm 11$ \\
AB-MAC & $83 \pm 18$ & $71 \pm 18$ & $70 \pm 21$ & $48 \pm 21$ & $48 \pm 18$ \\
\hline
\end{tabular}

MO were cultured on teflon foils with M-CSF $(100 \mathrm{ng} / \mathrm{ml})$, immunoglobulin $(\mathrm{Ig} ; 5 \mathrm{mg} / \mathrm{ml})$ or $5 \%$ AB-group serum (AB), respectively. After a culture period of 7 days, cells were harvested and surface antigens analysed by immunoperoxidase staining using $m A b$ antiCD14, anti-CD16, anti-CD71, MAX.1 and MAX.3. Data are given as percentage of antigen-positive MAC, mean of at least 3 experiments \pm SD.



Fig. 2. Phenotype analysis of different MO-derived MAC in plastic culture.

Monocytes were cultivated for 10 days in 96-well microtitre plates in the presence of either $10^{-8} \mathrm{M}$ $1,25(\mathrm{OH})_{2} \mathrm{D}_{3}, 5 \mathrm{mg} / \mathrm{ml}$ albumin or $5 \%$ human serum. Control cells were cultivated with medium alone. Antigen expression was analysed by cell ELISA and given as the percentage of $\beta$-2-microglobulin expression ( $\mathrm{AEI}=$ antigen expression index).

with albumin plus immunoglobulin (1D) exhibited a morphology very similar to MAC cultured in the presence of serum.

In addition to the morphology, maturation can be analysed by functional parameters, e.g. the capacity to secrete neopterin and TNF-alpha upon stimulation with LPS increases several-fold during the differentiation of MO into MAC. Table I shows a comparison of the functional activity between freshly isolated MO and MAC cultured with $5 \%$ serum, $100 \mathrm{ng} / \mathrm{ml} \mathrm{M}$-CSF or $5 \mathrm{mg} / \mathrm{ml}$ immunoglobulin, respectively. MAC derived from $\mathrm{MO}$ in the presence of M-CSF or immunoglobulin secreted only low amounts of TNF-alpha and neopterin, comparable to freshly isolated MO, whereas serum-derived MAC increased their secretion of these factors several-fold during culture. Table II outlines the distinct phenotypes of MAC derived from MO in the presence of either M-CSF, immunoglobulin or serum, respectively. The expression of maturation-associated antigens MAX.1, MAX.3 and CD16 is very low in M-CSF and immunoglobulin MAC when compared to serum MAC, while the transferrin receptor (CD71) is expressed equally well on the different MAC types. CD14 is downregulated during MO culture with M-CSF or immunoglobulin, while serum culture has no influence on CD14 expression. As both M-CSF and immunoglobulin were unable to induce serumtype MAC alone, and because of the capacity of albumin and $1,25(\mathrm{OH})_{2} \mathrm{D}_{3}$ to induce serum-like phenotype and morphology in plastic culture (fig. 2), we were interested in finding out whether competence could be improved by combining different factors. The combination of M-CSF with either $1,25(\mathrm{OH})_{2} \mathrm{D}_{3}$, immunoglobulin or albumin, respectively, was not able to replace serum. However, combining immunoglobulin, albumin and $1,25(\mathrm{OH})_{2} \mathrm{D}_{3}$ resulted in the generation of MAC comparable to those generated in serum cultures. Figures 3 and 4 show the effect of adding increasing amounts of $1,25(\mathrm{OH})_{2} \mathrm{D}_{3}, 25(\mathrm{OH}) \mathrm{D}_{3}$ and vitamin $\mathrm{D}_{2}$, respectively, to cultures containing immunoglobulin $(0.5 \mathrm{mg} / \mathrm{ml})$ and albumin $(0.5 \mathrm{mg} / \mathrm{ml})$. Cell survival (fig. 3) and secretion of TNF-alpha (fig. 4) were increased in a dose-dependent manner by the addition of $1,25(\mathrm{OH})_{2} \mathrm{D}_{3}$, whereas the non-active metabolite vitamin $\mathrm{D}_{2}$ had no effect at all. $25(\mathrm{OH}) \mathrm{D}_{3}$ did show activity, but only at higher concentrations (fig. 3 and 4). Similar good cell survival and high TNFalpha release were obtained without the addition of $1,25(\mathrm{OH})_{2} \mathrm{D}_{3}$ when the concentration of immunoglobulin as well as albumin was increased to $5 \mathrm{mg} / \mathrm{ml}$ each. We wanted to know whether these MAC, which were comparable to serum-derived MAC in terms of morphology and functional activity, also showed a similar antigen phenotype. FACS analysis of serum MAC and albumin/immunoglobulin MAC is shown in fig. 5. MO cultured with high 


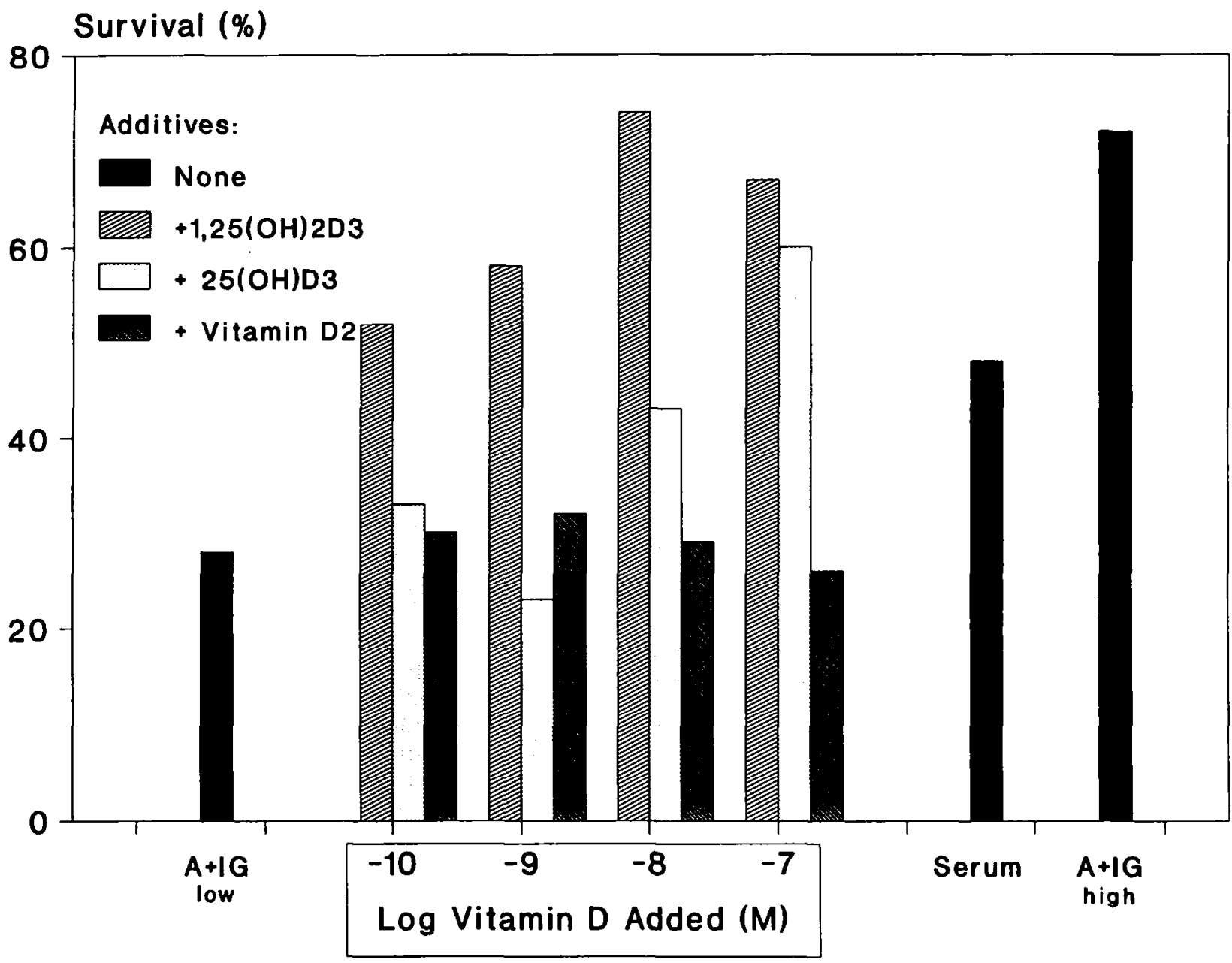

Fig. 3. Effect of $1,25(\mathrm{OH})_{2} \mathrm{D}_{3}$ on MO survival in teflon culture.

Monocytes were cultivated for 7 days on teflon foils with $0.5 \mathrm{mg} / \mathrm{ml} \mathrm{immunoglobulin} \mathrm{plus}$ $0.5 \mathrm{mg} / \mathrm{ml}$ albumin $\left(\mathrm{A}+\mathrm{Ig}\right.$, low), to which various concentrations of $1,25(\mathrm{OH})_{2} \mathrm{D}_{3}, 25(\mathrm{OH}) \mathrm{D}_{3}$ or vitamin D2 were added. Control cultures contained $5 \%$ serum or $5 \mathrm{mg} / \mathrm{ml}$ albumin plus $5 \mathrm{mg} / \mathrm{ml}$ immunoglobulin $(\mathrm{A}+\mathrm{Ig}$, high). At day 7, MAC were harvested and cell recovery determined by counting with trypan blue exclusion. Survival was expressed as percent seeded MO on day 0 .

amounts of albumin and immunoglobulin showed high expression of CD14, MAX.1 and CD16, comparable to MAC cultured in the presence of serum.

\section{Discussion}

The successful completion of the differentiation pathway from the immature precursor blood MO to mature MAC seems to be a central event in the ontogeny of the mononuclear phagocyte system. Cultivation of blood MO is a useful model to study regulatory signals involved in this maturation process. Whole serum induces MO to MAC matu- ration, but specific factors have not yet been clearly identified. There have been reports implicating $M$ CSF (Becker et al., 1987), IL4 (Te Velde et al., 1988) and immunoglobulin (Akiyama et al., 1988; Schreiber et al., 1991) in MO differentiation. M-CSF as well as immunoglobulin dramatically increase the cell yield compared to serum-free cultures, and may therefore act as survival factors for MO/MAC culture (Brugger et al., 1991). However, the secretory repertoire of M-CSF and immunoglobulin-induced MAC is low in contrast to serum-induced MAC, for which a high secretion of TNF-alpha and neopterin is a typical feature (Scheibenbogen and Andreesen, 1991 ; Andreesen et al., 1990). Phenotype analysis of 


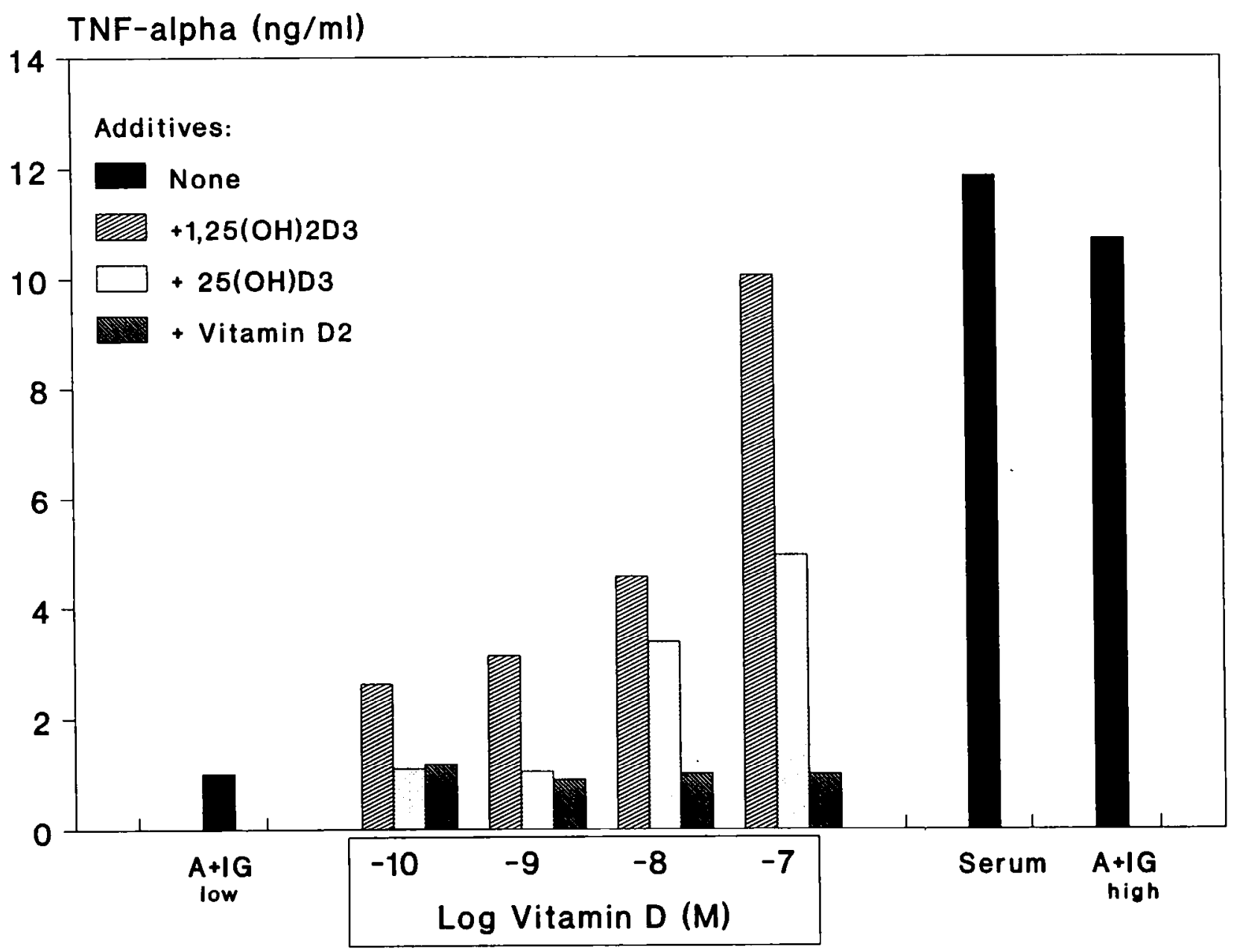

Fig. 4. TNF-alpha secretion of human $M A C$ induced by $1,25(\mathrm{OH})_{2} \mathrm{D}_{3}$.

Monocytes were cultured as described in legend to figure 3. MAC were seeded at $10^{6} / 2 \mathrm{ml}$ in 6-well plates with or without $100 \mathrm{ng} / \mathrm{ml} \mathrm{LPS}$, and TNF-alpha was measured by commercially available ELISA after $24 \mathrm{~h}$ of culture.

these $\mathrm{M}$-CSF and immunoglobulin MAC revealed a low expression of the maturation-associated antigens CD16 and MAX.1, which are highly expressed on serum-derived MAC (Clarkson and Ory, 1988; Andreesen et al., 1986). The transferrin receptor (CD71), which is also expressed on cells cultured under serum-free conditions (Andreesen et al., 1990) is found in comparable amounts under different culture conditions. Interestingly, CD14 is downregulated during MO cultivation with M-CSF or immunoglobulin. As CD14 has been postulated to be the receptor for the LPS-binding protein (Schumann et al., 1990; Wright et al., 1990), this might explain the low capacity of these cells to respond to LPS. In addition, M-CSF MAC and immunoglobulin MAC were smaller and less spread out than serum MAC. Thus,
MO cultivation with M-CSF or immunoglobulin allows the survival of $\mathrm{MO}$, but induces different MAC, which are "immature" in terms of morphology, phenotype and functional activity.

We then sought to determine whether combinations of different factors could substitute for serum in all parameters tested. Combinations of M-CSF with either $1,25(\mathrm{OH})_{2} \mathrm{D}_{3}$, albumin or immunoglobulin were not able to replace serum. However, addition of $1,25(\mathrm{OH})_{2} \mathrm{D}_{3}$ or albumin to immunoglobulincultured MO improved cell yield, functional activity and expression of the maturation-associated antigens MAX.1 and CD16. When used in suspension culture, $1,25(\mathrm{OH})_{2} \mathrm{D}_{3}$ and albumin alone or in combination induced differentiation of morphological and phenotypic mature MAC only in about $40 \%$ of the experi- 


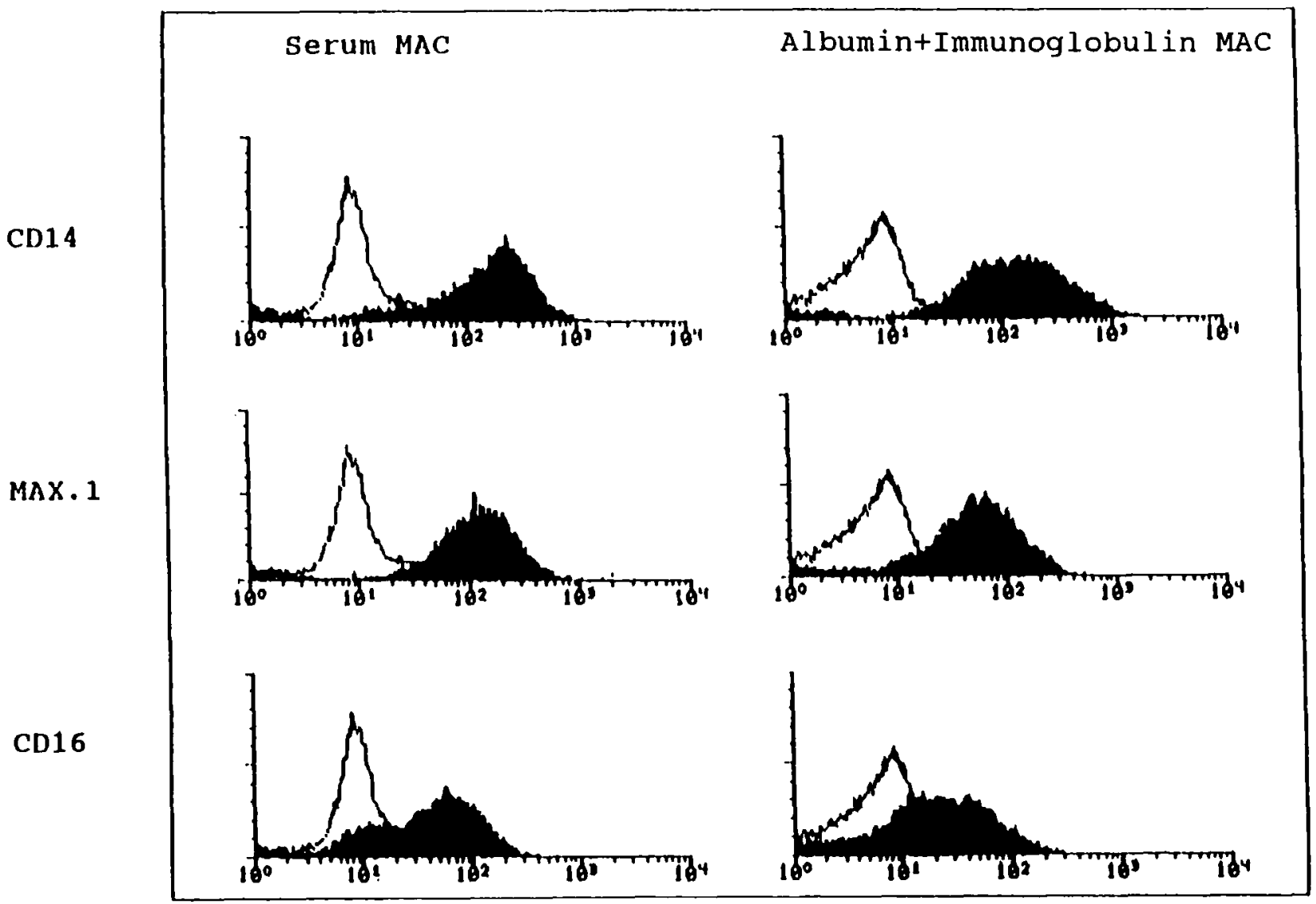

Fig. 5. FACS analysis of MO-derived MAC.

Monocytes were cultivated for 7 days on teflon foils with $5 \%$ serum or $5 \mathrm{mg} / \mathrm{ml}$ albumin plus $5 \mathrm{mg} / \mathrm{ml}$ immunoglobulin. Cells were harvested and FACS analysis performed as described in "Materials and Methods".

ments. In contrast, when cultured adherent to plastic substrates, $1,25(\mathrm{OH})_{2} \mathrm{D}_{3}$ and albumin consistently induced maturation of MO into MAC (Kreutz and Andreesen, 1990). Thus, adherence to plastic, similar to effects of immunoglobulin or M-CSF, may induce changes in cell biology that promote survival of $\mathrm{MO}$ in culture. However, $1,25(\mathrm{OH})_{2} \mathrm{D}_{3}$ and albu$\mathrm{min}$, in contrast to immunoglobulin and M-CSF, are also effective in inducing MO maturation in terms of morphology, phenotype and functional activity. A mixture of survival (e.g. immunoglobulin) and maturation-inducing $\left(e . g .1,25(\mathrm{OH})_{2} \mathrm{D}_{3}\right)$ activities seems to be necessary to generate competent serumtype MAC. Interestingly, M-CSF could not replace immunoglobulin in our combination experiments, even though both substances alone induced survival and showed a similar behaviour in all parameters tested. Thus, it can be assumed that high levels of exogenous M-CSF early in culture disturb the differentiation process, because in serum-containing cultures, an endogenous M-CSF secretion and a steady increase over the culture period is observed (not shown). Accordingly, normal serum levels of $\mathrm{M}$ CSF are relatively low $(2 \mathrm{ng} / \mathrm{ml}$; Shadle et al., 1989). As different types of M-CSF are present in serum (Hanamura et al., 1988), one recombinant M-CSF alone may be insufficient.

Whether the effect of high concentrations $(5 \mathrm{mg} / \mathrm{ml})$ of immunoglobulin and albumin and low doses $(0.5 \mathrm{mg} / \mathrm{ml})$ plus $1,25(\mathrm{OH})_{2} \mathrm{D}_{3}$ share a common mechanism cannot yet be answered. When albumins from different manufacturers, containing variable amounts of protein-bound $1,25(\mathrm{OH})_{2} \mathrm{D}_{3}$, were combined with immunoglobulin, we found no correlation between the amount of $1,25(\mathrm{OH})_{2} \mathrm{D}_{3}$ and the functional capacity and survival of these MAC (not shown). Therefore, we conclude that the effect of $1,25(\mathrm{OH})_{2} \mathrm{D}_{3}$ and albumin may be different. Since albumin is a transport protein for many hormones, other factors bound to albumin may contrib- 
ute to its maturation-inducing effect. Akiyama et al. reported that albumin in contrast to immunoglobulin is not able to induce differentiation in human MO, but they examined only the effect of albumin alone (Akiyama et al., 1988), not the combination of both serum proteins. Further investigations may answer the question as to whether albumin itself or factors bound to it contribute to this maturation-inducing activity.

In summary, we show that the maturation of blood MO into MAC in vitro is a phenomenon which seems not to be induced by a single factor; indeed, a combination of different factors may be necessary to promote MAC maturation comparable to that which occurs in serum.

\section{Acknowledgements} schaft.

This work was supported by Deutsche Forschungsgemein-

\section{References}

Akiyama, Y., Griffith, R., Miller, P., Stevenson, G.W., Lund, S., Kanapa, D.J. \& Stevenson, H.C. (1988), Effects of adherence, activation and distinct serum proteins on the in vitro human monocyte maturation process. J. Leuk. Biol., 43, 224-231.

Andreesen, R., Picht, J. \& Löhr, G.W. (1983), Primary cultures of human blood-born macrophages grown on hydrophobic teflon membranes. J. Immunol. Methods, 56, 295-304.

Andreesen, R., Mackensen, A., Osterholz, J. \& Löhr, G.W. (1988), Microculture assay for human macrophage maturation in vitro: cell ELISA analysis of differentiation antigen expression. Int. Arch. Allergy, 86, 281-284.

Andreesen, R., Bross, K.J., Osterholz, J. \& Emerich, F. (1986), Human macrophage maturation and heterogeneity: analysis with a newly generated set of monoclonal antibodies to differentiation antigens. Blood, 67, 1257-1264.

Andreesen, R., Scheibenbogen, C., Kreutz, M., Krause, S. \& Rehm, A. (1990a), Regulation of neopterin secretion during human monocyte to macrophage differentiation in vitro. Pteridines, 2, 59-61.

Andreesen, R., Brugger, W., Scheibenbogen, C., Kreutz, M., Leser, H.G., Rehm, A. \& Löhr, G.W. (1990b), Surface phenotype analysis of human monocyte to macrophage maturation. J. Leuk. Biol., 47, 490-497.

Becker, S., Warren, M.K. \& Haskill, S. (1987), Colonystimulating-factor-induced monocyte survival and differentiation into macrophages in serum-free culture. J. Immunol., 139, 3703-3709.

Bross, K.J., Pangalis, G.A., Staatz, C.G. \& Blume, K.G. (1978), Demonstration of cell surface antigens and their antibodies by the peroxidase-antiperoxidase method. Transplantation, 25, 331.

Brugger, W., Kreutz, M. \& Andreesen, R. (1991), Macrophage colony-stimulating factor is required for human monocyte survival and acts as a cofactor for their terminal differentiation to macrophages in vitro. J. Leuk. Biol., 49, 483-488.

Choudhuri, U., Adams, J.A., Byrom, N., McCarthy, D.M. \& Barett, J. (1990), 1,25-Dihydroxyvitamin D3 induces normal mononuclear blood cells to differentiate in the direction of monocyte-macrophage. Haematology, 23, 9-19.

Clarkson, S.B. \& Ory, P.A. (1988), Developmentally regulated IgG Fc receptors on cultured human monocytes. J. exp. Med., 167, 408-417.

Hanamura, T., Motoyoshi, K., Saito, M., Miura, Y., Kawashima, T., Nishida, M. \& Takuda, F. (1988), Quantitation and identification of human monocytic colony-stimulating factor in human serum by enzymelinked immunosorbent assay. Blood, 72, 886-892.

Johnson, W.D., Mei, B. \& Cohn, Z.A. (1977), The separation, long-term cultivation, and maturation of the human monocyte. $J$. exp. Med., 146, 1613-1625.

Kreutz, M. \& Andreesen, R. (1990), Induction of human monocyte into macrophage maturation by 1,25-dihydroxyvitamin D3. Blood, 76, 2457-2461.

Musson, R.A. (1983), Human serum induces maturation of human monocytes in vitro. Changes in cytolytic activity, intracellular lysosomal enzymes, and nonspecific esterase activity. Amer. J. Physiol., 111, 331-340.

Scheibenbogen, C. \& Andreesen, R. (1991), Developmental regulation of the cytokine repertoire in human macrophages: IL-1, IL-6, TNF-alpha and M-CSF. J. Leuk. Biol., 50, 35-42.

Schreiber, S., Blum, J.S., Stenson, W.F., MacDermott, R.P., Stahl, P.D., Teitelbaum, S.L.\& Perkins, S.L. (1991), Monomeric IgG2a promotes maturation of bone-marrow macrophages and expression of the mannose receptor. Proc. nat. Acad. Sci. (Wash.), 88, 1616-1620.

Schumann, R.R., Leong, S.R., Flaggs, C.W., Gray, P.W., Wright, S.D., Mathison, J.C., Tobias, P.S. \& Ulevitch, R.J. (1990), Structure and function of lipopolysaccharide-binding protein. Science, 249, 1429-1431.

Shadle, P.J., Allen, J.I., Geier, M.D. \& Koths, K. (1989), Detection of endogenous macrophage colonystimulating factor (M-CSF) in human blood. Exp. Hematol., 17, 154-159.

Te Velde, A.A., Klomp, J.P.G., Yard, B.A., de Vries, J.E. \& Figdor, C.G. (1988), Modulation of phenotypic and functional properties of human peripheral blood monocytes by IL-4. J. Immunol., 140, 1548-53.

Unanue, E.R. \& Allen, P.M. (1987), The basis for the immunoregulatory role of macrophages and other accessory cells. Science, 236, 551-557.

Van Furth, R. (1982), Current view on the mononuclear phagocyte system. Immunobiol., 161, 178-185.

Wewers, M.D. \& Herzyk, D.J. (1989), Alveolar macrophages differ from blood monocytes in human IL-1beta release. J. Immunol., 143, 1635-1641.

Wright, S.D., Ramos, R.A., Tobias, P.S., Ulevitch, R.J. \& Mathison, J.C. (1990), CD14, a receptor for complexes of lipopolysaccharide (LPS) and LPS binding protein. Science, 249, 1431-1433.

Yamauchi, K., Martinet, Y. \& Crystal, R.G. (1987), Modulation of fibronectin gene expression in human mononuclear phagocytes. J. Clin. Invest., 80, 1720-1727. 